\title{
TUNTEET PALAUTETILANTEESSA:
}

\section{"HERNE PATJAN ALLA VAI LESKEN- LEHTI TIEN PIENTAREELLA?"}

Artikkeli käsittelee tunteiden merkitystä päiväkotityöyhteisön palautteenannossa. Palautteen jakamisen yhtenä suurena esteenä koetaan pelko vastapuolen tunteiden loukkaamisesta ja omien tunteiden kaaoksesta tällaisen kokemuksen jälkeen. Empaattinen ja herkkä ammattikunta ei haluaisi loukata eikä asettua itse uhkaavaan asemaan antamalla työtoverille rehellistä palautetta tämän työskentelytavasta. Oman ja toisten työn avoin arviointi on vaarassa ja näin toiminta saattaa ohjautua kunkin henkilön oman "mutu"-tuntuman kautta. Sijaiskärsijöiksi joutuu itse työn kohde,lapset.

\section{TUULIKKI VENNINEN}

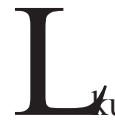

ähestyn aihetta oman kokemukseni, työyhteisön kehitysprosessin läpikäymistä uvaavan kirjan, päivähoidon aiheesta tekemäni pro gradu -tutkimuksen sekä päiväkotityöyhteisössä toteutettavan toimintatutkimuksen kautta.

Tutkimusteni kohteena on ammatillinen palaute, jossa eri osapuolten tunteet nousevat keskeisen tärkeiksi. En tarkastele sitä, missä asemassa tunteet työyhteisön kokonaistoiminnassa ovat. Sitä ovat kuvanneet esimerkiksi Suojanen ja Nakari (Suojanen 1992, 31; Nakari 2003, 51) Damasio on kuvannut yksityiskohtaisesti tunteiden syntyä. (Damasio 2003, 38-48) Lähden ajatuksesta, että ne ovat työyhteisössä keskeisiä (Ks. Turunen 1999). Pyrkimykseni on tuoda esille, että tunteet ohjaavat merkittävästi ammatillistakin työskentelyä, jos niiden ilmenemistä ei opetella hallitsemaan.

\section{KYMMENEN VUOTTA SITTEN}

1991 perustamani päiväkotityöyhteisö koki kriisin toimittuaan muutaman vuoden. Kriisin kulminaatiopisteeksi muodostui kartoitus, jonka mukaan ilmapiiri oli romahtanut edellisenä vuonna erinomaiseksi arvioidusta ilmapiiristä. Johta- jana pyysin työnohjausta koko työyhteisölle ja saatuani myönteisen päätöksen kirjoitin alaisilleni kirjeen, jonka avulla toivoin saavani kosketuksen näiden tunteisiin ja sitä kautta tunteet avuksi yhteiseen ponnistukseen. Seuraavassa otteita kirjeestä:

\section{Työkaverit!}

Siitä on kohta kolme vuotta, kun urakka alkoi. Olimme onnellisia uudesta työpaikasta...... Puoli vuotta on mennyt ja talo natisee

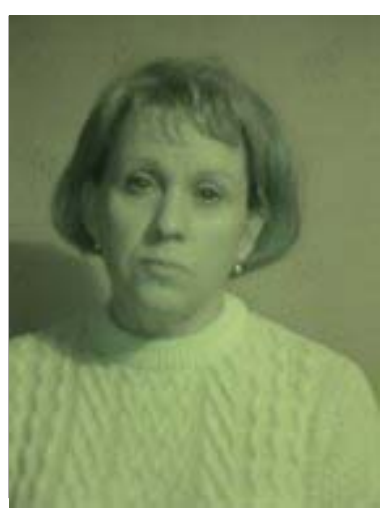

Tuulikki Venninen liitoksissaan...

Meidän on uskaltauduttava yksin, paljaana itsenämme tarkastella työpaikkaamme - mikä siinä on kunnostuksen tarpeessa. Pienikin asia voi olla ensiarvoisen tärkeä. Tuo asia on rohjettava sanoa siitäkin huolimatta, että se pahoittaisi jonkun työkaverin mielen tai että se olisi kaverin mielipidettä vastaan. Muuten emme saa tarttumakohtaa sille, mistä voisi olla apua. Jos nyt uskallamme itkeä, niin ehkä vielä joskus saamme iloita juuri siksi, että uskalsimme...

Vielä nyt saamme tehdä työtä elävässä talossa, jossa tunteet saavat olla pinnassakin. Mutta jol- 
lemme uskalla olla avoimia toisillemme, tulee aika, jolloin opimme hymyilemään, vaikka jokin surettaa meitä. Se pelottaa minua, enkä suostu sellaista taloa pystyssä pitämään.

En halua yhtään sälyttää teidän harteillenne omasta vastuustani. Uskon vilpittömästi, että minä, jolla valtaakin on eniten, olen suurimmat virheet tehnyt. Mutta teidän suuri velvollisuutenne on näyttää ne minulle. Muuten olemme hukassa. En pyydä muuta kuin-että antaisitte kaikkenne. (Venninen ym. 2001)

Tämän jälkeen alkoi muutosprosessi päiväkodissamme, jonka etenemistä kuvaamme yhdessä tuottamassamme kirjassa (2001). Lainauksista käy selville, kuinka vahvasti negatiiviset tunteet sitovat energiaa ja heikentävät työtehoa - hiertävät kuin herne paljan alla.

"Varmaan lapset vaistosivat joskus, kun asiat 'kytivät' osastolla tai kun osastolla tai käytävillä "keskusteltiin".

"Kovilla oli! Oli kiva itkeä ensin parkkipaikalla ja aloittaa päivän työt”.

"Kireä ilmapiiri verotti lapsilta. Aikuisilla oli munta ajateltavaa." (Emt.)

Työnohjaajanamme toiminut Kiesiläinen (1998) painottaakin, että vuorovaikutustyötä, etenkin lasten kanssa työtä tekevät ihmiset reagoivat maailmaan usein hyvin tunnevaltaisesti. Lasten olemuksen ja toiminnan "hahmo" nousee aikuisten yhteisöön, joka alkaa muistuttaa monessa suhteessa lasten yhteisöä. Asioihin suhtaudutaan tunnevaltaisesti ja ristiriitojen selvittely on vaikeaa. (Kiesiläinen 1998, 84-85) Sama asia on tullut esille omassa tutkimuksessani. (Venninen 2002)

Työnohjaus oli kahden viikon välein illalla, puolitoista tuntia kerrallaan. Taitavan työnohjaajan avulla uskaltauduimme puhumaan hyvin suoraan. Asiat olivat usein kipeitä, mutta jokaisen kerran jälkeen oli parempi olo. Isokorpi (2003) toteaakin, että kun ryhmässä yhteisesti tarkastellaan jäsenissä syntyneitä tunteita, jokaisen on mahdollista oppia paljon itsestään ja siitä, miten oma käyttäytymien ryhmässä vaikuttaa muissa herääviin tunteisiin. (Isokorpi 2003, 32)

\section{Työnohjauksen kautta saadaan lupa ongelmien läpikäymiseen \\ Opetellaan rakentavia ratkaisuja \\ Työnohjaus opetti tosi paljon niistä asioista,}

jotka ovat merkityksellisiä kun tehdään työtä yhdessä.

Arvokeskustelut alkoivat. ( Venninen ym.2001)

Yksilöitä ja heidän tekemisiään miettiessäni opettelin tarkkailemaan omia ja muiden reaktioita ja pohtimaan niihin johtavia syitä. Pääsin entistä syvemmälle toimintatapojeni ja tunteitteni tiedostamisessa. Mezirowin (1998) mukaan uudistavassa oppimisessa reflektiolla onkin aivan erityinen tehtävä. Ne ennakko-oletukset, joille uskomuksemme rakentuvat on uskaltauduttava asettamaan uudelleenarvioinnin kohteeksi. Merkitysperspektiivimme saattavat sen tuloksena uudistua ja sitä kautta meillä on mahdollisuus oivaltaa toimintamme uudelta kannalta. (Mezirow 1998, 35) Opin ymmärtämään yksilön ja yhteisön prosesseja ja huomasin kykeneväni vaikuttamaan niihin omalla toiminnallani.

\section{VIITEKEHYS PALAUTTEEN TUTKIMISELLE}

\section{Itsetuntemus}

Luftin ja Jungin jo 50-luvulla kehittämä Joharin ikkuna on yksi jäsennystapa toimijan itsensä tiedostamien ja tiedostamattomien sekä hänen kanssaan vuorovaikutuksessa olevien "muiden" tiedostamien ja tiedostamattomien piirteiden tarkasteluun. Mallin luomaa viitekehystä voidaan käyttää hyväksi niin oman itsen kuin ryhmänkin toiminnan tarkastelussa. (Luft 1984)

Valitsin kyseisen teoriamallin yhdeksi tutkimukseni viitekehyksen muodostajaksi, sillä se tuo selkeästi esille sen, mitä palautteen annolla pyritään aikaansaamaan: oman toiminnan näkemisen ulkopuolisen silmin. Ylikoski (1993) on kuvannut omiin tunteisiin tutustumisen myönteistä kehää, jossa Joharin ikkunan kaltaisesti tiedostamisen ja avautumisen kautta vapautuu sisäistä energiaa. Tämä tapahtuu suojautumisen ja asioiden piilottamisen tarpeen vähetessä. (Isokorpi ym. 2001, 90) Ruohotien (1999) mukaan palaute voidaan jakaa myös sisäiseen, työstä itsestään nousevaan ja työntekijän itse kokemaan palautteeseen sekä ulkoiseen, muista ihmisistä lähtevään palautteeseen. (Ruohotie 1999, 85) Tässä tutkimuksessa keskityn jälkimmäiseen. Olen tutustuttanut työyhteisön kokonaisuudessaan malliin ja näin olemme saaneet työskentelyn pohjaksi yhteisiä käsitteitä. 


\section{PALAUTE}

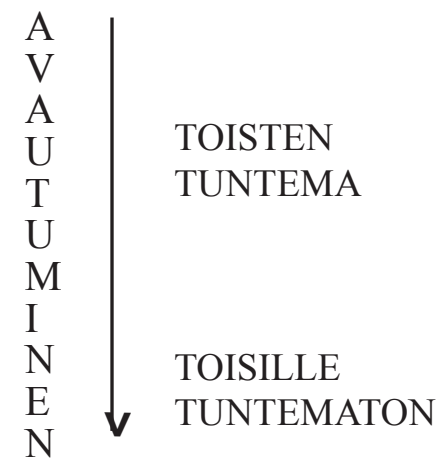

Itselle tunnettu Itselle tuntematon

Kuvio 1. Joharin ikkuna (Luft 1984)

JULKINEN eli tunnettu minä

Siihen sisältyy vapaasti ja turvallisesti ilmaistavia asioita ja tunteita, kerromme esimerkiksi päivän kuulumisia ystävälle. Alueeseen sisältyy myös rooliminä, jossa voi esiintyä turvallisesti. Mitä laajempi tämä alue on, sitä vapaammin ilmaisemme itseämme. Viestintä on enimmäkseen avointa ja annamme toisille oikean kuvan itsestämme. Vieraassa ryhmässä avoimuus saattaa olla vähäisempää kuin tuttujen seurassa.

SOKEA eli toisen näkemä minä

Tämä alue käsittää sellaisia persoonallisuutemme puolia, joita emme itse huomaa. Ne ovat ominaisuuksia, tapoja, tottumuksia ja normeja, jotka toiset ihmiset huomaavat meissä (kielenkäytön piirteitä, asenteellisuutta, eleitä, maneereita, läpinäkyviä tunteita, asioita joilla tiedostamattamme ärsytämme muita, torjuttu omakuva, vahvuudet, joita vähättelemme, sekä persoonallisuuden piirteitä, joita emme itse arvosta, mutta joita muut arvostavat.) Kun saamme toisilta palautetta sokeasta minästämme, pystymme kehittämään paremmin itsetuntemustamme.

YKSITYINEN eli salattu minä

Alue kätkee sisälleen henkilökohtaiset asiamme, joita emme halua näyttää toisille tai jotka jäävät muille salaisiksi pidättyvyytemme takia. Salaiset asiat voivat olla ilon, mutta myös surun asioita. Siihen saattaa liittyä myös tahdikkuus, jolloin vältämme sanomasta asioita mielestämme liian suoraan. Myös epävarmuus ja pelko sekä käytös, jota haluamme peittää muilta (liika innokkuus, epäily, pelko tietämättömyys) voi liittyä tähän alueeseen. Jos yksityinen alue on kovin laa- ja ja vie elämässämme paljon tilaa, voi asioiden salaamiseen kulua niin paljon energiaa, ettei muuhun toimintaan tahdo jäädä voimia.

\section{TUNTEMATON minä}

Tuntematon minä on tuntematon sekä itselle että muille. Siihen liittyy alitajunta ja kokemukset, jotka olemme unohtaneet, tiedostamaton torjunta sekä tuntemattomat voimavarat. Tämäkin osa vaikuttaa persoonallisuuteemme ja toimintaamme. Yllättävissä tilanteissa saatamme reagoida tavalla, jota emme itsekään ymmärrä.

Mitä laajempi on julkisen toiminnan alue niin yksilö- kuin ryhmätasollakin, sitä helpompi on tulla toimeen muiden kanssa. Tämän vuoksi alue pitäisi siis saada niin suureksi kuin mahdollista. Muilta saatu palaute auttaa meitä valloittamaan julkisen toiminnan alueeksi asioita, jonka suhteen helposti olemme itse sokeita. Eleidemme vaikutusten kannalta on ratkaisevinta se, mitä signaaleja muut ottavat vastaan, ei se, mitä kuvittelemme lähettävämme. Palautteen avulla tajuamme ehkä sen tosiasian, että hymymme saatetaan kokea väheksyvänä, katseemme ylimielisenä tai katsekontaktin puute osoituksena pelosta tai haluttomuudesta kommunikoida muiden kanssa. Nyt, kun asia on tullut tietoisuuteemme, voimme itse pyrkiä vaikuttamaan siihen ja pyytää työtovereiltamme palautetta siitä, miten onnistumme. (Emt.)

Jos samaan aikaan tapahtuu henkilön itsensä avautumista (hän kertoo esimerkiksi muille, että kokee olonsa tietyissä tilanteissa turvattomaksi), pienenee yksityinen alue ja julkinen kasvaa edelleen. Yhteisen tietämyksen ja toistemme tunte- 
muksen lisääntyessä asioita ja merkityksiä nousee pinnalle, sellaisiakin, joista ennen ei oltu tietoisia. Tuntematon alue pienenee ja ymmärretään yhä uusia leimaa antavia piirteitä ihmisten välillä. (Emt.) Isokorpi \& Viitanen (2001) kuvaavatkin tunteiden kahdenlaista tietomerkitystä. Toisaalta ne liittyvät tuttuun ja tiedettyyn, mutta ne viestittävät myös jostain tuntemattomasta, jota vasta aavistellaan. (Vrt. Joharin ikkunan tuntematon osuus, kuvio 1.)

Olin huomannut jo työnohjauksen avulla, että tunteen tullessa tietoiseksi, esille ja hyväksyttäväksi, se menettää jo suurimman otteensa kantajastaan. Selkeästi asioista sopimalla ja rohkeasti vaikeuksista toisillemme kertomalla meille jäi voimaa itse työhön. Yhteinen ymmärrys perustehtävästämme päiväkodissa alkoi muodostua. (Vrt. Joharin ikkunan julkinen osuus, kuvio 1). Myös Turunen (1999) painottaa, että ihminen reagoi aina tunteillaan. Joskus se tapahtuu avoimesti, joskus taas kätketysti.

Kiesiläinen (1998) painottaa, että vuorovaikutus alkaa vaatia taitoja siinä vaiheessa, kun tulee ristiriitoja ja ongelmia. Aikuisuuteen tulisi kuulua kyky kantaa vastuu omista ajatuksista, tunteista ja teoista. Tunne ja teko eivät ole sama asia, eivätkä ihmisten välille aiheuta ristiriitaa niinkään negatiiviset tunteet kuin kyvyttömyys säädellä omia tekoja tunteiden seurauksena. Ammatti-ihmisen on kyettävä tunnistamaan sellaiset omat tunteet, jotka helposti tuottavat vuorovaikutusta tuhoavaa tai estävää käyttäytymistä. On lupa olla kateellinen, mutta ei tehdä sen varjolla pahaa. (Kiesiläinen 1998, 52-55) Isokorpi (2003) toteaa puolestaan, että yksilön on koettava ryhmässä hyväksytyksi tulemisen ja turvallisuuden tunteita pystyäkseen tehokkaasti oppimaan. Oma subjektiivinen kokemukseni onkin, etten olisi turvattomaksi itseni kokevana kyennyt omia puutteitani johtajana niin avoimesti käsittelemään.

\section{MENETELMÄ JA TULOKSET}

\section{Aineistot artikkelin pohjana}

Työyhteisöni yhdessä (2001) kirjoittama kirja "Perttu Muutoksessa - päiväkodin kehitystarina". Teos kuvaa työyhteisön jäsenten kokemuksia muutosprosessissa. Kirjoittamiseen osallistui jokaisesta päiväkodin henkilöstöryhmästä (johtaja, lastentarhanopettaja, lastenhoitaja, avustaja, keittäjä ja siivooja) henkilö, joka kuvasi jonkin subjektiivisen kokemuksensa. Vaikka itse työn- ohjauksen jälkeinen kehitysprosessimme toteutettiin itsenäisesti ja intuitiivisesti yhteisömme aikaisempien kokemusten ohjaamana, tieteellistä kiinnostavuutta sille antavat useat koko henkilökunnalle suunnatut avoimet kyselyt. Kysymykset koskivat työntekijöiden käsityksiä työyhteisön kehitykseen vaikuttaneista asioista. Teokseen on liitetty runsaasti suoria lainauksia työntekijöiden kuvauksista. (Venninen ym. 2001)

Pro gradu -tutkimus vuodelta 2002 pohjautuu vuotta aikaisemmin kunnan kaikille päiväkotityöntekijöille suunnattuun kyselyyn ammatillisen palautteen annosta ja siihen vaikuttavista tekijöistä työyhteisössä. Tutkimusongelmia lähestyin kvalitatiivisen tutkimuksen keinoin avointen kysymysten kautta. Päiväkoteja oli kunnassa 12, mutta yksi päiväkodeista jätti kokonaan vastaamatta. Vastauksia sain takaisin 81 , jolloin vastausprosentiksi muodostui $84 \%$. Tulosten tulkinta eteni analyysin ja synteesin vuorottelulla, joiden avulla lähtestyin ongelmia monelta suunnalta. Tutkimustuloksia vertasin Karila \& Nummenmaan (2001) esittämiin päiväkodin keskeisiin osaamisalueisiin. (Venninen 2002)

Keskeneräinen väitöskirja-aineisto rakentuu puolitoistavuotisesta (1.1.2003 - 31.5.2004) päiväkotityöyhteisön toimintatutkimuksesta, jossa paneudutaan palautteen annon ammatilliseen kehittämiseen. Materiaalia on kerätty numeraalisten arvioiden, oppimispäiväkirjojen, haastattelujen ja erilaisten kirjallisten kuvausten avulla. Aineiston kvalitatiivinen analyysi on aloitettu ja ensimmäiset kvantitatiiviset tulokset on saatu.

\section{Palaute ja tunteet}

Olin kehittynyt johtajana sen avulla, että alaiseni uskaltautuivat antamaan minulle rehellistä ja suoraa palautetta. Halusin selvittää, miten työntekijät päiväkodeissa yleensä kokevat palautteenannon.

Pro gradu -tutkimukseni (2002) kohdistui palautteen mahdollisuuksiin päiväkodin työntekijän ammatillisen kasvun tukemisessa. Kun kysyin, mikä on vaikeinta palautteen antamisessa, yli puolessa työntekijöiden maininnoista nousi esille pelko toisen tunteiden loukkaamisesta. Samoin pelätiin henkilökohtaisuuksiin menemistä. Myös palautteen antajan omat tunteet ja epäsuosioon joutuminen nousivat pelottavina asioina esiin. Pelättiin, ettei negatiivista palautetta annettaessa osata löytää oikeita sanoja, joka estäisi näin ymmärretyksi tulemisen. Vastaanottajan reagointi ja 
mahdollinen eripura koettiin ilmapiiriä heikentävänä asiana. (Venninen 2002)

- Suurin syy antamisen vaikeuteen on omassa luonteessa. Pelkään vastaanottajan reagointia ja mahdollista eripuraa. En halua työskennellä riitaisessa ilmapiirissä.

- Esimies: Rakentavan palautteen antaminen niin, että palautteen saajan kohdalla puhumme samasta asiasta ilman raskasta tunnelatausta.

- Kun työtoveri on ns. "kävellyt ylitseni", on vaikea sanoa, että se loukkasi minun itsetuntoa$n i$.

- En uskalla sanoa: olet aina myöhässä, olet laiska, annat muiden ottaa vastuun .(Emt.)

Kysymykseen siitä, millaisia esteitä palautteen annolle koetaan päiväkodissa olevan joku totesikin, että esteinä on tunteiden hallitsematon kuohunta. Oma ensireaktiokin palautetta vastaanotettaessa pelottaa, vaikka tiedettäisiin toisen olevan oikeassa. Yleisesti koettiin, että työntekijät eivät oikeasti osaa eivätkä uskalla antaa palautetta ja että negatiivista palautetta on totuttu saamaan niin vähän, että se pelottaa. Myös kehuttuna olon jotkut kokivat vaikeaksi. Työntekijät kiinnittivät huomiota siihen, että negatiivisen palautteen henkilökohtaiselle käsittelylle ei aina anneta aikaa. (Emt.)

Esteinä pelko siitä, että osaanko antaa palautetta ja ottaa sitä vastaan. Mitä muut ajattelevat! Mielistelenkö? Valehtelenko?

- Syyllistyn joskus myös murjotukseen ja kostan puhumattomuudella.

- Hyvää palautetta ei osaa ottaa ihan luontevasti. Siihen oppii kyllä kaiken aikaa. Negatiivinen palaute aina vähän kirvelee, sieppaa, suututtaa, milloin mitäkin.

- Se ettei ihmiselle anneta aikaa pureskella palautetta eikä ihmiset (palautteen antaja) aina

\begin{tabular}{|l|c|c|l|l|}
\hline Vaikeus palautteen antamisessa & $\begin{array}{c}\text { Henkilökunta } \\
\mathbf{\%}\end{array}$ & $\begin{array}{l}\mathbf{f} \\
\mathbf{8 3}\end{array}$ & $\begin{array}{l}\text { Esimiehet } \\
\mathbf{\%}\end{array}$ & $\begin{array}{l}\mathbf{f} \\
\mathbf{8}\end{array}$ \\
\hline Negatiivisenpalautteen antaminen & & & & \\
loukkaamtta toista & 54 & 45 & 38 & 3 \\
Saada itsensä ymmärretyksi & 21 & 17 & 13 & 1 \\
Kiitos & 7 & 6 & - & - \\
Omat tunteet & 6 & 5 & - & - \\
Joutuminen epäsuosioon & 6 & 5 & - & - \\
Ei vaikeaa & 5 & 5 & - & - \\
Ajankohdan löytyminen & 1 & 1 & 49 & 4 \\
\hline
\end{tabular}

TAULUKKO 1

Käsitykset siitä, mikä on vaikeinta palautteen antamisessa (henkilökunta $n=56$, esimiehet $(n=8)$

\begin{tabular}{|l|c|c|l|l|}
\hline Vaikeus palautteen vastaanottamisessa & $\begin{array}{c}\text { Henkilökunta } \\
\mathbf{\%}\end{array}$ & $\begin{array}{l}\mathbf{f} \\
\mathbf{4 9}\end{array}$ & $\begin{array}{l}\text { Esimiehet } \\
\mathbf{\%}\end{array}$ & $\begin{array}{l}\mathbf{f} \\
\mathbf{6}\end{array}$ \\
\hline Negatiivisen palautteen vastaanottaminen & & & & \\
loukkaantumatta & 30 & 14 & 17 & 1 \\
Jos palautetta ei koeta oikeudenmukaiseksi & 10 & 5 & 17 & 1 \\
Kehuttuna olo & 14 & 7 & 17 & 1 \\
Ei anneta aikaa sulautella palautetta & 14 & 7 & - & - \\
Ottaa onkeensa & 8 & 4 & - & - \\
Ei mitään & 8 & 4 & - & - \\
Muut & 16 & 8 & 49 & 3 \\
\hline
\end{tabular}


ymmärrä, että ei sitä hymyssä suin voi ottaa vastaan! Eikä muutos parempaan tapahdu "silmän räpäyksessä”. (Emt.)

Kysyttäessä millaisista asioista päiväkodin työntekijät kaipaisivat lisää palautetta perustyöhön liittyvien toiveiden määrä oli yli kolmasosa kaikista maininnoista.

- tavallisesta arkisesta työstä, siitä miten perustyö sujuu, jaksamisesta, uutteruudesta ja ideoista. Haluaisin myös negatiivista palautetta enemmän, sellaista rakentavaa ja varovaisesti sanottua.

- reilusti ja suoraan sanottuna, ilman suuria tunteenpurkauksia, ja että on mahdollisuus puolustautua. (Emt.)

Jokaisessa talossa oli useita mainintoja esimiehen antamasta sanattomasta palautteesta, jota alaiset lukevat ilmeiden, eleiden ja äänensävyjen kautta.

- Kyllähän palautteen näkee myös vahvasti ilmeistä ja äänensävyistä. Se usein kolahtaa enemmän kuin sanat.

- Esimies: Ilmeillä ja eleillä, vaikka en aina itse olekaan huomannut (muut sanovat että näkivät lävitseni). Kokouksissa nyökyttelen tai joskus tunnen, kun puna alkaa nousta kaulaa myöten. - Myös ilmeet, eleet kertoo paljon, jonkun puhumattomuus myös palaute (Emt.)

Yleisesti koettiin, että palautteen annolla voi päiväkodissa vaikuttaa erittäin moniin asioihin. Varsin yleinen maininta oli, että ei taida olla asiaa, johon sillä ei voitaisi vaikuttaa. Kannustava palaute on auttanut jaksamaan paremmin, piristänyt mieltä ja saattanut työntekijän onnelliseksi. Työilmapiiri nousi tärkeimmäksi asiaksi, johon palautteen annon lisäämisellä voidaan tuoda parannusta. Se mainittiin yli kolmasosassa vastauksia.

- myönteisyyteen ja iloisuuteen, yleiseen viihtyvyyteen, asioiden rakentavaan ratkaisuun, ennalta ehkäisyyn, yhteishenkeen

- Asioita voidaan tehdä paremmin, opitaan virheistä, ei jää puhumattomia asioita.

- Korjaava palaute saa taas ottamaan itseä niskasta kiinni ja parantamaan, kannustava palaute auttaa jaksamaan ja kohottaa myös itsetuntoa.

- Palautteen saaminen, oli se sitten hyvä tai huonoa, niin se laittaa pohtimaan miten toimitaan. (Emt.)

\section{PAREMPAAN}

\section{PALAUTTEESEEN}

Tutkimukseni (2002) syvensi mielenkiintoani siitä, onko palautteen annolla ja sen yhteisellä harjoittelulla mahdollista kehittää ammatillista osaamista päiväkotiyhteisössä. Halusin välttää kirjallisuuden esiin tuomia karikoita. Niin Goleman (1998), Ruohotie (1999) kuin Heikkilä \& Heikkilä (2001) painottavat kasvokkain tapahtuvan harjoittelun merkitystä ja siitä saadun kokemuksen hyödyntämistä teoriatiedon avulla. Erilaisten arviointimuotojen esittelyn sijasta tulisi kehittää havainnointiin liittyviä valmiuksia.

Keski-Luopa (2001) ja Isokorpi (2003) taas painottavat kokemuksellisen oppimisen ja siinä vaikuttavien tunteiden merkitystä. Kokemuksellisessa oppimisessa on tärkeintä oman kokemuksen käyttöönottaminen. Tämä ei tapahdu ilman vahvaa persoonallista sitoutumista siihen oppimiseen, johon kokemuksen kautta pyritään. Tunteet ovat tärkeä osa kokemusmaailmaa ja kokemuksellista oppimisprosessia. Ne liittyvät olennaisesti vuorovaikutukseen ja niiden ilmaiseminen vaikuttaa ihmisen kokonaisvaltaiseen hyvinvointiin. Keltikangas-Järvinen (2000) painottaa, että ihminen oppii tunnistamaan itseään toisten ihmisten kautta. Schein (1999) toteaakin osuvasti, että "It takes two to see one". Toisen henkilön avulla voimme saada kosketuksen myös sokeisiin puoliin itsessämme. (Goleman 1998, 312313; Ruohotie 1999, 78-82; Heikkilä \& Heikkilä 2001, 23-24; Keski-Luopa 2001, 205; Isokorpi 2003, 26; Keltikangas-Järvinen 2000, 16; Schein 1999, 130,140)

Uskoin, että palautetilanteissa esiintyvät tunteet olisivat opittavissa hallitsemaan niin, että palaute muuttuisi yhä tehokkaammaksi ja työskentelyä hyödyntävämmäksi. Aikaisemman kehitysprosessin läpikäyneenä tiesin kokemuksesta, että muutos vaatii aikaa. Sain mahdollisuuden toteuttaa väitöskirjatutkimukseni puolentoista vuoden mittaisena toimintatutkimuksena yhdessä vastanneista päiväkodeista. Vuoden 2003 alusta käynnistyi koko päiväkodin henkilökuntaa koskeva kehittämishanke, jonka tavoitteena oli yhteisen harjoittelun ja kehittelyn avulla saada tietoa palautteenantoon liittyvistä asioista ja muodostaa mahdollisimman tehokas palautteenantokäytäntö päiväkotiin. Oma roolini muodostui varsin pian osallistuvaksi toimintatutkijaksi. Koska koulutin kuukausittain henkilökuntaa ja pyrin 
auttamaan heitä käsitteellistämään erilaisia ilmiöitä en katsonut alunperinkään voivani toimia pelkkänä fasilitaattorina. Tein tietoisen ratkaisun aktiivisesta roolista, jota myös työyhteisö minulta odotti. Varsinaisena suunnittelu- ja tarkastelukumppanina minulle toimi päiväkodin henkilöstöstä muodostettu kuusihenkinen ohjausryhmä, johon myös päiväkodin johtaja kuului.

Tärkeimpänä toimintaa kehittävänä työkaluna oli tiimiläisten toisilleen antama kuukausittainen arvio kyseisen tiimiläisen ammatillisesta palautteenannosta. Kukin työntekijä siis arvioi itsensä sekä kunkin työryhmänsä jäsenen palautteenantotapaa sen pohjalta, noudattiko se hyviä, yhdessä luotuja ohjeita. (Ks. liite)

Jatkotutkimukseni tulokset ovat vielä muotoutumassa, sillä aineiston keruu päättyy toukokuussa 2004. Palautteenannossa tunteet näyttelevät vain yhtä osaa. Jo nyt on käynyt selville, että niiden vaikuttavuutta on mahdotonta jättää huomiotta. Jokaisessa palautetilanteessa ne joko auttavat tai estävät palautteen onnistumista. Siksi onkin tärkeää, että tunteiden vaikuttaminen tiedostetaan, jolloin osataan paneutua oikeisiin asioihin, kun toimintatutkimuksen etenemistä reflektoidaan.

Golemanin (1998) mukaan ihmiset, jotka ovat tietoisia omista tunteistaan, ymmärtävät myös, miten tunteet liittyvät siihen, mitä he ajattelevat, sanovat tai tekevät. Hyvän itsekurin omaava työntekijä kykenee hallitsemaan haitallisten tunteiden ja mielihalujen ilmenemistä. Tämä tunnetaito on ikään kuin näkymätön, se ilmenee vain rajujen tunteenpurkausten puutteena. (Goleman 1998, 105-106) Tämänhetkisen tutkimukseni kuluessa olen huomannut, että suurta pelkoa aiheuttaa palautteen antaminen henkilölle, jonka reagointi on ennalta arvaamatonta. Näin palautetta annettaessa ei tiedetä, mihin tulisi varautua. Kuitenkin asiaan paneutumalla voidaan pyrkiä eliminoimaan haittaavia tekijöitä.

- Me emme onnistu tässä! Tää palautteiden anto meidän kahden kanssa ei onnistu! Ei voi olla tarkotus, että toista satutetaan koko ajan, siihen mä en suostu !!! Mulla on tosi paska olo, mä voin henkisesti ja fyysisesti huonosti. En usko, että sen pitää olla tällasta! (Venninen, Julkaisematon lähde)

-Uskalsin rehellisesti myöntää pelkääväni antaa palautetta hänelle ja toivoin myös, että tästä lähin on aina kolmas henkilö paikalla kun annamme rakentavaa palautetta, jotta pysyisim- me asiassa. (Emt.)

-Olin sairas ja pahalla tuulella. Ilmoitin ja varoitin hlökuntaa.(Emt.)

Hyvän itsekurin omaavan henkilön merkkinä voi olla myös vihamielisen ihmisen käsittely ilman vastahyökkäystä. Runsaan vuoden kuluessa varsinkin tutkimukseen osallistuvien työntekijöiden itsekurin hallinta on kehittynyt. Haastattelussa ilmeni useita mainintoja siitä, kuinka kyseinen henkilö oli kyennyt pidättäytymään oman ärtymyksensä ja suuttumuksensa esiintuomisesta kokiessaan itseensä kohdistuvan hyökkäyksen. Selvästi ylpeinä he toivat esille asian, jossa eivät aikaisemmin olleet onnistuneet. Goleman (1998) painottaa, ettei tunteiden hallinta tarkoita todellisten tunteiden kieltämistä tai tukahduttamista. Tunnetaitoisuus tarkoittaa, että voimme valita, miten ilmaisemme tunteitamme. (Goleman 1998, 103)

- Että se opettaja oli hirveen hyökkäävä kun hän tuli mua puhelimeen ja mua vastaan. Ni mä huomasin sen että mä pystyin pitää itteni rauhallisena että vaikka se reuhas ja huus siel toises päässä ni mä olin koko ajan et mä en lähteny siihen mukaan.

- Sit mä olin tosi vihanen ku mä sen luurin laskin ni sit mä painoin tälleen et mä purin sen vihan siinä., mut en menny siihen mukaan et mä olin koko ajan asiallinen ja koko ajan puhuin asiasta ja pysäytin hänet aina et nyt kuuntelet et me ollaan niinku tässä. Et se oli hyvä, et se ei oo niinku mua - mut nyt se oli mua. (Venninnen, Julkaisematon lähde)

\section{AMMATTI-IHMINEN EROTTAA TUNTEEN JA TEON}

Vuorovaikutustyöntekijän työtä vaikeuttavat usein omat tai toisen puolustavat tunteet. Ammatti-ihmisen erottaa kuitenkin siitä, että hän osaa erottaa tunteen ja teon. Loukkaantuminen on yksi niistä tunnekokemuksista, jotka on opittava vuorovaikutustyössä nopeasti käsittelemään itsessä, ettei työ kärsi. (Kiesiläinen 1998, 52-55, 103) Olemme joutuneet kiinnittämään huomiota omiin ja työtovereiden erilaisiin puolustautumismekanismeihin. Niihin tutustumisen kautta on opittu ottamaan asialle aikalisä, jos kyvyt eivät sillä hetkellä ole riittäneet asian käsittelyyn. Kuitenkin on opittu myös asiaan palaamisen taito. Yhä 
useammin palautepapereista on luettavissa henkilön kehittyminen kykynä palata asiaan tai sitkeytenä puida asiaa, kunnes se saavuttaa molemminpuolisen selvyyden.

Olen saanut Liisalta sekä positiivista että korjaavaa palautetta. Käsittelimme erästä hankalaa asiaa, jonka tiimoilta palasimme asiaan useita kertoja. Liisa on palautteen vastaanottajana aktiivinen ja tarvittaessa pyytää lisäpalautetta. (Venninen, julkaisematon lähde.)

Mä en niinku, ku on ihan normaalissa olotilassa niin sillon jotenkin jaksaa ja pystyy ottamaan sen palautteen silleen et ei tuu niinku puolustuskannalle mut sit jos on väsynyt tai muuta ni mul tulee hyvin herkästi se et nyt mä en jaksa kuunnella ja sit mä vaan mietin ja mietin sitä omaa tunnetilaa. Ja sit tulee se et mun täytyy niinku, et nyt lopeta, mä en enää kuuntele. (Emt.)

Ihmiset eivät yleensä kerro tunteistaan sanoilla, vaan viesti välittyy äänensävyjen, ilmeiden ja muiden sanattomien keinojen avulla. Taito tulkita pieniä vihjeitä perustuu etenkin itsetuntemukseen ja itsekuriin. Jos emme ymmärrä omia tunteitamme tai pysty hallitsemaan niitä, emme voi tajuta muidenkaan mielialoja.(Vrt. palauteohje: Antajan oma tunnetila). Tällaista samalle kanavalle virittäytymista varten on pakko työntää omat tunteensa väliaikaisesti sivuun, jotta toisen viestit pääsisivät läpi. Vahvojen tunteiden vallassa emme huomioi pieniä merkkejä, jotka voisivat auttaa yhteisymmärrykseen. Empatian perusedellytyksenä on itsetuntemus, omien ruumiillisten merkkien havaitseminen. Työssä havaitsemme koko ajan näitä tunnevihjeitä ja säätelemme toimintaamme niiden mukaan. (Goleman 1998, 162, 165) Varsinkin palautetilanteessa on tarkkailtava jatkuvasti vastapuolesta välittyviä vihjeitä. (Vrt. palauteohje: Lue kumppania) Niiden mukaan palautteenantaja voi vielä kertaalleen tarkentaa sanomaansa tai joskus jopa "ottaa aikalisän", jotta vastapuoli voi "koota itsensä".

Myös palautteen vastaanottajan empatiataidot ovat tärkeitä. Kuuntelemisen taito on työelämässä tarpeellinen ja kysyy myös taitoa. Ensimmäinen vaatimus on kyky kertoa omasta kuunteluvalmiudesta. Hyvä, syventyvä kuunteleminen tarkoittaa muutakin kuin puheen vastaanottoa; siihen liittyy kyselemistä ja keskustelukumppanin ajatusten esittämistä omin sanoin. Näin syntyy molemminpuolinen ymmärrys. (Goleman 1998,
167-168) Palautetta vastaanottaessamme olemmekin harjoitelleet aktiivisuutta. Vastuu palautetilanteen onnistumisesta on myös palautteen vastaanottajalla.

- Mulla tuli mieleen et mikä on ollu vaikeinta ni kyl se on se ollu se, ainakin alussa se oma reagointi, just se että ei rupee puolustelemaan heti vaan se että se kuuntelu toimii et jaksaa kuunnella ettei keskeytä toista, ni se on ollu kans vaikeeta. (Venninen, julkaisematon lähde)

Kiesiläisen (1998) mukaan epäonnistumisen myöntäminen ja tilanteen analysointi yhdessä kollegojen kanssa on parasta koulutusta ihmissuhdetyössä. (Vrt. palauteohje: Auttaen) Siksi vuorovaikutustyötä tekevien tulee voida keskustella toistensa kanssa säännöllisesti ja päästä sitä kautta irti epäonnistumisten aiheuttamasta syyllisyyden tunteesta. Vuorovaikutustyössä joudutaan erityisen paljon kiinnittämään huomiota puhuttuun juuri siksi, että sen avulla on mahdollisuus myös käsitellä tunteita. (Kiesiläinen 1998, 22-25, 42-43, 73, 125-126)

\section{POHDINTA}

Halusin selvittää tunteiden merkitystä palautteen jakamisessa sekä sitä, voidaanko kyseisissä tilanteissa oppia hallitsemaan omia tunteita ja ottamaan huomioon vastapuolen tunteita. Tutkimustulokset viestivät, että pelko toisten tunteiden loukkaamisesta ja omien haavoittamisesta ohjaa palautteenantoa. Voidaan päätellä, että tunteet ovat tärkeällä sijalla vuorovaikutustyössä. Varsin yleinen viittaus tutkimuksen (2002) vastauksissa oli pelko tunteiden hallinnan menettämisestä. Tunteet ikään kuin toimisivat omalla voimallaan, ilman että ihminen itse kykenisi niihin juuri vaikuttamaan. Tunteiden varjelun halua kuvaavat vastaukset, joissa kerrottiin kokemuksia negatiivisen palautteen "verhoamisesta" nimettömäksi muuttamalla se passiiviin tai kertomalla asia toisen henkilön välityksellä.(Vrt. Palauteohje: Minä-muoto) Onnistunutta palautetilannetta sen sijaan kuvattiin oppimiskokemuksena, josta kumpikin osapuoli oppi jotakin. (Venninen 2002) - Negatiivista epäsuoraa (kuin jotkut voi ..., miksi jotkut....)

- Itse sanoin suoraan jostain asiasta. Toinen osapuoli kuunteli. Meni päiviä ja hän kertoi kuinka hän oli loukkaantunut sanoistani. Hämmästyin 
koska en ollut tarkoittanut asiaa niin kuin hän oli ymmärtänyt. Puhuimme asiasta jälkeenpäin. Kumpikin huomasimme että ihmiset ajattelevat todella eri tavoin. Opimme kumpikin tilanteesta. (Emt.)

Onnistuneeseen palautetilanteeseen liittyy palautteen antamisen ja vastaanottamisen professionalisoituminen. Tällöin molemmilla osapuolilla on selkeä kuva tilanteeseen vaikuttavista seikoista ja omista vaikuttamismahdollisuuksista niiden ilmenemiseen, kuten myös taitoa hoitaa tehtävä hyvin.

- Olet tasainen palautteen jakaja, annat sekä positiivista että korjaavaa palautetta.

- Kuuntelet keskittyneesti ja kommentoit mielelläsi. Annat palautetta luontevasti ja kiinnität huomiota muiden palautteenantoon ja vastaanottamiseen. (Venninen, julkaisematon lähde)

Tutkimuksessa (2002) nousi erittäin vahvana tarve koulutuksen ja harjoittelun järjestämiseen. Sitä koski yli kolmasosa työntekijöiden maininnoista ja reilusti yli puolet esimiesten maininnoista. Koulutuksen avulla kaivattaisiin uutta tietoa yhteistyöstä ja vuorovaikutuksen lainalaisuuksista sekä itse palautteen antamisesta. Samaa asiaa painottavat useat tutkijat (esim. Goleman 1998; Ruohotie 1999; Heikkilä \& Heikkilä 2001;Ronthy-Östberg ym. 2000). Nyt, toimintatutkimustani reflektoidessani voin itse yhtyä kantaan ja todeta, että koulutuksen ja ennen kaikkea yhteisen harjoittelun avulla palautteen annossa ja siihen liittyvässä tunteiden huomioimisessa voidaan selvästi kehittyä, mutta se vaatii paneutumista jokaiselta osapuolelta.

Tunneäly ei tarkoita tunteiden valtaan antautumista, vaan perusajatuksena on tunteiden hallinta niin, että ne ilmaistaan asianmukaisesti ja tehokkaasti, jotta ihmiset pystyvät työskentelemään yhteisten tavoitteiden eteen. Näin tunteet voivat olla apuna tavoitteellisen toiminnan ylläpitämisessä. (Goleman 1998; Isokorpi \& Viitanen 2001) Tunneäly ja tunnetaidot ovat juuri sitä, mitä päivähoidon vuorovaikutustyötä tekevät ihmiset itsekin kokevat kaipaavansa.

Kasvatustyötä on mahdollista tehdä lukemattomilla tavoilla hyvin, mutta yhtä monella tavalla sitä voi tehdä huonosti. Tämän vuoksi sitä on rehellisesti arvioitava. Korostunut hienotunteisuus toista henkilöä, opettajaa tai johtajaa, koh- taan saa aikaan sen, että kaikki tuntevat osaavansa tehdä työnsä ja olevansa arvostettuja työyhteisössä. Asian liiallisella korostamisella on kuitenkin varjopuolensa. Toisen loukkaamisen pelossa ei tartuta havaittuihin epäkohtiin asioiden korjaamiseksi. Näin tilanteen paraneminen vaikeutuu, sillä ongelmia ei koko työyhteisön tasolla välttämättä edes tiedosteta. (Kiesiläinen 1998; Huusko 1999) Sekä oman että muiden tutkimusten perusteella katson välttämättömäksi pysähtyä miettimään, mikä kasvatustyössä on oleellista. Huolehditaanko joskus lasten tarpeiden kustannuksella työtovereiden hyvästä mielestä? Varhaiskasvattajan koulutukseen voisi mielestäni liittää tunneälyyn liittyvien ominaisuuksien tarkastelua ja harjoittelua. Kun opetellaan työskentelyä, jossa on kohdattava työtoverit kokonaisina persoonallisuuksina ei voida olla käsittelemättä siihen tarvittavia taitoja. Vasta omien tunteiden hallinnan myötä muodostuu halu käyttää tunteita hyväksi työssä. Silloin uskaltaudutaan siivoamaan herneet patjan alta, jotta voimia riittäisi huomata leskenlehdet tien pientareella.

\section{LÄHTEET}

Damasio, A. (2003). Spinozaa etsimässä. Ilo, suru ja tuntevat aivot. Terra Cognita.

Goleman, D. (1998) Tunneäly työelämässä. Otava.

Heikkilä, J. \& Heikkilä, K.(2001). Dialogiavain innovatiivisuuteen.WSOY.

Huusko, J. (1999). Opettajayhteisö koulun omaleimaisten vahvuuksien hahmottajana, käyttäjänä ja kehittäjänä. Joensuun yliopiston kasvatustieteellisen tiedekunnan julkaisuja 49.

Isokorpi, T. \& Viitanen, P. (2001). Tunnevoimaa! Tammi.

Isokorpi, T. (2003). Tunneälytaitojen ja yhteisöllisyyden oppiminen reflektoinnin ja ryhmäprosessin avulla. Hämeenlinnan ammattikorkeakoulu.

Karila, K., Nummenmaa, A-R. (2001). Matkalla moniammatillisuuteen. Kuvauskohteena päiväkoti. WSOY.

Keltikangas-Järvinen, L. (2000). Tunne itsesi, suomalainen. Wsoy.

Kiesiläinen, L. (1998). Vuorovaikutusvastuu. Ammatilliset vuorovaikutustaidot kasvatusyhteisössä. Arator. 
Mezirow, J. (1995). Uudistava oppiminen: kriittinen reflektio aikuiskoulutuksessa. Helsingin yliopiston Lahden tutkimus- ja koulutuskeskus.

Nakari, M-L. (2003). Työilmapiiri, työntekijöiden hyvinvointi ja muutoksen mahdollisuus. Jyväskylän yliopisto.

Ronthy-Östberg, M., Rosendahl, S., Liber, AB. 2000. Keskustelu kehittää. WSOY.

Ruohotie, P. (1999). Palkitseva ja kannustava johtaminen. Edita.

Schein, E. (1999) Process Consultation Revisit-ed. Building the helping Relationship. Addison-Wesley.

Suojanen, U. (1992) Toimintatutkimus koulutuksen ja ammatillisen kehittymisen välineenä. Finn Lectura Ab.

Turunen, K.E. (1999) Opetustyön perusteet. Atena Kustannus Oy.

Venninen, T., Nivarpää-Ampuja, H. (2001). Perttu muutoksessa. Päiväkodin kehitystarina. PS-kustannus.

Venninen, T. (2002). Palaute - ammatillisen kasvun kompassi? Pro gradu -tutkielma. Helsingin yliopisto.

Venninen, T. Julkaisematon lähde. Keskeneräinen väitöskirjatyö. Helsingin yliopisto.

Ylikoski, M. (1993). Työyhteisö muиtosmurroksessa. Ihmisyys muutoksen kohtaamisessa ja johtamisessa. Työturvallisuuskeskus.

\section{LIITE}

\section{KUUKAUSITTAISEN PALAUTTEEN ANNON ARVIOINTIOHJE}

- Ei jaa itsenäisesti palautetta eikä ole harjoituksissa motivoitunut asiaan

- ei reagoi annettuun palautteeseen tai kokee sen hyökkäyksenä itseään kohtaan

- arvostelee toisten työskentelyä "sivussa"

$$
2
$$

- jakaa satunnaisesti epämääräistä palautetta

- vastaanottaa palautetta tilanteesta ja mielentilasta riippuen eikä muuta toimintaansa sen mukaan

- toisinaan arvostelee sivussa muita työntekijöitä

- jakaa jonkin verran joillekin ammatillista pa- lautetta, ei kuitenkaan korjaavaa, eikä toimi ohjeiden mukaan

- palaa asiaan tarvittaessa arvioimaan palautteennatotilannetta

- toimii aktiivisesti ja osittain ohjeiden mukaan

- ottaa vastaan palautetta aktiivisesti

- jakaa monille positiivista ammatillista palautetta sekä rohkenee myös joskus antamaan korjaavaa palautetta

- on sisäistänyt hyvän palautteenantotavan

- ei lannistu epäonnistumisista, vaan uskaltautuu tarkastelemaan, missä meni vikaan ja yrittämään uudelleen

- palautteen vastaanottajana aktiivinen ja korjaa tarvittaessa toimintaansa

- antaa pyydettäessä palautetta myös työntekijän tavasta antaa ja ottaa vastaan palautetta

5

- jakaa kaikille monipuolista ammatillista palautetta (kuukauden aikana jokaiselle erilaisista asioista)

- on sisäistänyt hyvän palautteenantotavan

- palautteen vastaanottajana aktiivinen, kyselee lisää ja pyytää tarkennuksia, palaa asiaan tarvittaessa.

- korjaa toimintaansa palautteen suuntaisesti ja pyytää lisäpalautetta

- auttaa ja rohkaisee muita jakamaan palautetta ja tarkastelemaan onnistumisiaan siinä

- antaa palautetta myös työtovereiden tavasta antaa ja vastaanottaa palautetta

- palautteen vastaanottajana aktiivinen ja korjaa tarvittaessa toimintaansa (Venninen, julkaisematon lähde)

Artikkeli saapui toimitukseen 11.3.2004. Se hyväksyttiin julkaistavaksi toimituskunnan kokouksessa 15.4.2004. 